\title{
IMPLEMENTASI PENDIDIKAN KARAKTER SISWA KELAS V DI SD NEGERI 6 DAWUHAN KABUPATEN SITUBONDO TAHUN PELAJARAN 2017/2018
}

\author{
Rindi Rahmawati Istiqomaria, Aenor Rofek \\ Program Studi Pendidikan Guru Sekolah Dasar Fakultas Keguruan dan Ilmu Pendidikan \\ Universitas Abdurachman Saleh Situbondo (UNARS) \\ Jln. PB. Sudirman No. 7 Situbondo \\ E-mail: RindiRahmawati19@gmail.com dan gonzalesrofik99@gmail.com
}

\begin{abstract}
The implementation of character education is through habituation, namely three religious values, discipline values, and environmental care values. Whereas the learning of character values through habituation in SD Negeri 6 Dawuhan, Situbondo District is carried out through programmed activities, routine activities, and spontaneous activities. This study aims to determine the implementation of the implementation of character education for fifth grade students at SD Negeri 6 Dawuhan, Situbondo, 2017/2018 school year, and the subjects of this study were all fifth grade students of SD Negeri 6 Dawuhan, Situbondo, 2017/2018 Academic Year with the number of respondents 34 student. The school is the total sample of 208 students. This study included a qualitative descriptive study. Data sources use primary data and secondary data, while the technique for determining informants is 4 people. Data retrieval method uses observation, interviews, questionnaires, documentation. Data analysis techniques used are data collection, data reduction, data presentation and conclusion drawing. While to test the validity of the data the researcher used observation persistence and triangulation techniques.
\end{abstract}

Keywords: Implementation, Character Education

\section{LATAR BELAKANG}

Pendidikan merupakan sarana utama dalam membentuk dan menciptakan sumber daya manusia yang berkualitas, baik melalui pendidikan informal maupun pendidikan formal. Berdasarkan UndangUndang No. 20 Tahun 2003 Pasal 1 Ayat 1, pendidikan adalah usaha sadar dan terencana untuk mewujudkan suasana belajar dan proses pembelajaran agar peserta didik secara aktif mengembangkan potensi dirinya untuk memiliki kekuatan spiritual keagamaan, pengendalian diri, JURNAL IKA VOL 7 No. 1 JUNI 2019 | 46 kepribadian, kecerdasan, akhlak mulia, serta keterampilan yang diperlukan dirinya, masyarakat, bangsa dan Negara. Pendidikan juga termasuk proses untuk memberikan manusia berbagai macam situasi yang bertujuan memberdayakan diri. (Suyomukti, Nurani 2015, 21)

B.J. Habibie (dalam Muhammad D., 2011: 2) menyatakan bahwa "manusia senantiasa harus mampu menciptakan sinergi positif antara tiga unsur yaitu kebudayaan, agama dan ilmu pengetahuan dan teknologi, mengingat ketiga unsur 
tersebut merupakan kunci dari peradaban manusia (civilization)". Pembentukan watak atau karakter kebangsaan yang kuat diharapkan mampu menghasilkan peserta didik yang berpegang teguh pada budayanya sendiri tetapi mampu beradaptasi dengan perkembangan jaman.

$$
\text { Berbagai alternatif solusi }
$$
permasalahan karakter bangsa diajukan sebagai upaya solutif dan preventif untuk mengatasi permasalahan karakter bangsa. Salah satu kajian yang banyak dibahas terkait dengan mengatasi permasalahan karakter bangsa adalah pendidikan karakter. Pendidikan dianggap sebagai alternatif yang bersifat preventif untuk mengatasi masalah budaya dan karakter bangsa karena pendidikan mampu mengembangkan kualitas generasi bangsa dalam berbagai. Oleh karena itu, pendidikan memiliki peran yang vital dalam pembentukan karakter bangsa.

Disisi lain bangsa Indonesia mengalami permasalahan yang sangat besar terkait dengan karakter bangsa. Permasalahan budaya dan karakter bangsa tengah menjadi sorotan berbagai pihak baik pada tingkat lokal, nasional, maupun internasional. Berbagai problematika kehidupan yang muncul di masyarakat Indonesia seperti korupsi, kekerasan, kejahatan seksual, kehidupan politik yang tidak produktif, dan lain-lain telah menjadi topik yang hangat pada berbagai media dan berbagai forum Perubahan paradigma masyarakat Indonesia dalam berpikir dan bertindak di era globalisasi, terutama di kalangan generasi muda sering tidak sesuai dengan kepribadian dan karakter bangsa akibat terpengaruh oleh nilai-nilai dan budaya asing.

Sekolah sebagai lembaga formal merupakan sarana dalam rangka pencapaian tujuan pendidikan. Melalui sekolah, siswa belajar berbagai macam hal, dalam pendidikan formal, belajar menunjukan adanya perubahan yang sifatnya positif sehingga pada tahap akhir akan didapat keterampilan, kecakapan dan pengetahuan baru.

Proses implementasi pendidikan karakter bagi guru dan siswa dalam kultur sekolah menjadi sangat urgen dalam membentuk karakter siswa yang lebih kuat. Proses tersebut menjadi lebih efektif apabila terimplementasi pada individuindividu sejak usia dini. Demikian halnya pada satuan pendidikan, bahwa penanaman nilai-nilai karakter pada satuan pendidikan dasar seperti di sekolah-sekolah dasar sangat mutlak dibutuhkan sebagai pembentukan karakter siswa di masa yang akan datang. Hal ini sangat mendukung tujuan dari pendidikan di sekolah dasar dalam meletakkan dasar-dasar kecerdasan baik intelektual, sosial, emosional, maupun 
spiritual guna mempersiapkan peserta didik untuk mengikuti pendidikan pada jenjang yang lebih lanjut. (Kusuma,Doni 2012: 65)

Berdasarkan hasil observasi awal di SD Negeri 6 Dawuan Kabupaten Situbondo diperoleh informasi bahwa, mengenai implementasi strategi pembelajaran pendidikan karakter dalam sekolah dasar telah dilakukan di salah satu SD, yaitu SD Negeri 6 Dawuhan Kabupaten Situbondo, salah satu contoh dalam menanamkan implementasi karakter yaitu terkait kedisiplinan, setiap pagi guru di SD Negeri 6 Dawuhan Kabupaten Situbondo selalu datang lebih awal ke sekolah, hal ini menunjukkan sikap bentuk kedisiplinan, sehingga bagi siswa yang datang terlambat akan mendapatkan sanksi. Hal ini bertujuan agar siswa di SD Negeri 6 Dawuhan bisa tepat waktu dalam berbagai kegiatan pembelajaran di sekolah. Selain itu guru di SD Negeri 6 Dawuhan juga mengajarkan sikap sopan santun kepada siswanya, karena guru sangat berperan dalam mengoreksi sikap tersebut. Salah satu cara yang dilakukan guru adalah dengan cara selalu mengingatkan kepada siswa tentang sikap yang baik terhadap orang lain. Namun apabila terdapat siswa yang melakukan tindakan tidak sopan, maka sebagai pendidik harus mengingatkan, bukan memarahi melainkan memberikan tindakan yang bersikap positif. Oleh karena itu, SD Negeri 6 Dawuhan berupaya mengembangkan pembelajaran pendidikan karakter melalui aktivitas pembiasaan untuk seluruh siswa di lingkungan sekolah. Salah satu pembiasaan yang dilakukan yaitu setiap siswa SD Negeri 6 Dawuhan diwajibkan menyanyikan lagu kebangsaan "Indonesia Raya" di setiap awal jam pembelajaran secara bersama-sama. Pembiasaan tersebut dimaksudkan untuk menanamkan nilai semangat kebangsaan. Selain itu, masih terdapat beberapa dinamika implementasi dalam penanaman nilai-nilai karakter pada kultur sekolah yang perlu digali lebih dalam oleh peneliti.

Berdasarkan latar belakang yang telah diuraikan di atas, peneliti tertarik untuk melakukan penelitian yang berjudul "Implementasi Pendidikan Karakter Siswa Kelas V di SD Negeri 6 Dawuhan Kabupaten Situbondo Tahun Pelajaran 2017/2018". Penelitian ini diharapkan untuk mengetahui adanya implementasi pendidikan karakter siswa kelas V di SD Negeri 6 Dawuhan Kabupaten Situbondo tahun pelajaran 2017/2018.

\section{METODE PENELITIAN}

Pendekatan yang digunakan dalam penelitian ini adalah pendekatan kualitatif deskriptif adalah suatu metode dalam 
meneliti status sekelompok manusia, objek, serta kondisi, sistem pemikiran ataupun suatu kelas peristiwa pada masa sekarang. Menurut David (dalam Moleong, 2012: 5) menyatakan bahwa penelitian kualitatif merupakan pengumpulan data pada suatu latar alamiah, dan dilakukan oleh orang atau memberi peneliti yang tertarik secara alamiah. Adapun data yang di kumpulkan berupa kata-kata tertulis dari orang-orang dan perilaku yang dapat diamati.Hal ini disebabkan oleh adanya penerapan metode kualitatif.

Pendekatan kualitatif digunakan dalam penelitian ini karena pada hasilnya nanti diinginkan berupa paparan dan uraian tentang apa saja yang dilakukan sekolah /guru dalam pelaksanaan model pendidikan karakter siswa kelas V di SD Negeri 6 Dawuhan Kabupaten Situbondo.

Kehadiran peneliti diperluan dalam setiap peneitian guna untuk memperoleh data yang valid dan objektif. Kehadiran peneliti mencakup tiga tahapan untuk terjun langsung dalam pencarian data. Adapun tahapan-tahapan penelitian tersebut meliputi tiga tahapan.

Pada tahap awal, penelitian ini dilakukan sebelum peneliti melakukan penelitian dilapangan. Bahkan tahapan ini termasuk kategori tahapan awal sebelum menentukan judul penelitian. Dalam tahapan ini meliputi beberapa aspek, yaitu: pertama, menentukan judul dimana peneliti berusaha mendaftarkan beberapa judul yang diperoleh melalui referensi atau data.

Kedua setelah tahapan awal selesai maka tahapan selanjutnya adalah peliputan ke lapangan.Pada peliputan ini, peneliti terjun langsung kelapangan untuk mencari data-data dari beberapa sumber.

Selanjutnya tahapan terakhir dalam setting penelitian adalah pasca penelitian, dimana peneliti sudah merampungkan penelitiannya dengan berbagai data yang diperoleh.Pada tahapan ini tugas peneliti adalah mengelolah data, menulis data, mengurai data, memahami data.

Tempat penelitian adalah tempat peneliti dapat menangkap keadaan yang sebenarnya dari objek yang akan diteliti. Adapun lokasi penelitian ini adalah di SD Negeri 6 Dawuhan Kabupaten Situbondo.

Sedangkan waktu penelitian ini direncanakan pada bulan April sampai Agustus 2018. SD Negeri 6 Dawuhan Kabupaten Situbondo bertempat di kawasan pedesaan, namun kegiatan belajar mengajar berjalan secara efektif, lancar dan nyaman karena didukung dengan lingkungan masyarakat yang didukung serta didukung dengan adanya konstuk bangunan gedung yang komplit serta di sesuaikan dengan lokasi yang memadai keberadaan siswa-siswi dan guru. 
Setiap peneliti diperlukan adanya data untuk di analisis dan dikaji. Data merupakan rekaman atau gambaran atau keterangan tentang suatu hal atau fakta. Data penelitian bisa berupa tulisan, cerita atau informasi dan dokumen. Sedangkan sumber data adalah dari mana data penelitian tersebut diperoleh. Tentu untuk memperoleh data tersebut yang diteliti diperoleh dari dua sumber : sumber primer dan sumber sekunder.

Pengumpulan data menurut adalah berbagai cara yang digunakan untuk mengumpulkan data, menghimpun, mengambil, atau menjaring data penelitian. Penentuan pengumpulan data sangat tergantung pada jenis data dan sumber data yang akan dicapai. Oleh karena itu dalam penelitian metode dalam pengumpulan data yang digunakan adalah:

a. Observasi

Observasi bisa diartikan sebagai pengamatan dan pencatatan secara sistematis terhadap gejala yang tampak pada objek penelitian. Dalam penelitian ini, observasi yang dilakukan oleh peneliti dengan melakukan pengamatan terhadap Implementasi pendidikan Karakter siswa kelas V di SD Negeri 6 Dawuhan Kabupaten Situbondo.

b. Wawancara

Wawancara atau interview adalah vara menjaring informasi atau data melalui interaksi verbal/lisan Peneliti menggunakan wawancara interview terstruktur, karena dengan interview terstruktur dapat dipersiapkan rupa pertanyaan- pertanyaan yang diperlukan, agar hanya fokus mengulas pokok- pokok permasalahan yang akan diteliti.

c. Angket

angket adalah teknik pengumpilan data yang dilakukan dengan cara memberi seperangkat pertanyaan atau pernyataan tertulis kepada responden untuk dijawabnya. Angket merupakan teknik pengumpulan data yang efisien jika peneliti tahu dengan pasti variabel yang akan diukur dan tahu apa yang tidak bisa diharapkan dari responden.

d. Dokumentasi

Studi dokumenter merupakan suatu teknik pengumpulan data dengan menghimpun dan menganalisis dokumendokumen baik dokumen tertulis, gambar maupun elektronik

analisis data terdapat tiga alur aktivitas/ kegiatan yang harus dilakukan peneliti yaitu reduksi data, penyajian data, dan penarikan kesimpulan. Adapun langkah-langkah dalam melakukan analisis data dalam bentuk bagan. Penjelasannya sebagai berikut:

1. Pengumpulan data

Dalam melakukan analisis data peneliti memerlukan pengumpulan data 
yang dengan menyajikan hasil observasi, wawancara, dokumentasi dan studi kepustakaan serta melakukan analisis data terhadap masalah yang ditemukan di lapangan.Sehingga dapat diperoleh gambaran yang jelas tentang objek dalam penelitian ini yaitu tentang implementasi pendidikan karakter siswa kelas V di SD Negeri 6 Dawuhan Kabupaten Situbondo.

2. Reduksi Data

Pada langkah ini data yang diperoleh dicatat dalam uraian yang terperinci.Dari data-data yang sudah dicatat tersebut, kemudian dilakukan penyederhanaan data. Data yang dipilih hanya data yang berkaitan dengan masalah yang akan dianalisis, dalam hal implementasi pendidikan karakter siswa kelas V di SD Negeri 6 Dawuhan Kabupaten Situbondo. Informasiinformasi yang mengacu pada permasalahan itulah yang menjadi data dalam penelitian ini.

3. Penyajian Data

Pada langkah ini, data-data yang sudah ditetapkan kemudian disusun secara teratur dan terperinci agar mudah dipahami.Data-data tersebut kemudian dianalisis sehingga diperoleh tentang implementasi pendidikan karakter siswa kelas V di SD Negeri 6 Dawuhan Kabupaten Situbondo.
4. Penarikan Simpulan/ Verifikasi

Pada tahap ini dibuat kesimpulan tentang hasil dari data yang diperoleh sejak awal penelitian.Kesimpulan ini masih memerlukan adanya verifikasi (penelitian kembali tentang kebenaran laporan) sehingga hasil yang diperoleh benar-benar valid. Ketiga komponen tersebut saling berkaitan dan dilakukan secara terus-menerus mulai dari awal, saat penelitian berlangsung sampai akhir laporan.

\section{HASIL DAN PEMBAHASAN}

\section{Implementasi pendidikan karakter} melalui pembiasaan di SD Negeri 6 Dawuhan Kabupaten Situbondo

Data hasil observasi yang dilakukan oleh peneliti tentang penerapan strategi pembelajaran pendidikan karakter melalui pembiasaan di SD Negeri 6 Dawuhan Kabupaten Situbondo dilaksanaan melalui tiga pembiasaan yaitu pembiasaan religus, disiplin, dan peduli lingkungan.

\section{a. Religius}

Pembiasaan nilai religius dibagi menjadi dua kategori yaitu sikap religius dan perilaku religius. Sikap religius meliputi:

1) Berpartisipasi dalam kegiatan pondok ramadhan. Sementara itu pada saat pondok ramadhan siswa diberikan materi yang berkaitan dengan 
peningkatan pemahaman keagamaan yang sudah terjadwal. Kegiatan pondok ramadhan di SD Negeri 6 Dawuhan Kabupaten Situbondo dilaksanakan selama dua hari. Hari pertama serentak mulai dari kelas I sampai kelas VI di kumpulkan di dalam kelas untuk mendengarkan ceramah tentang puasa yang di wakili oleh salah satu guru. dan pada hari berikutnya (hari ke dua) diberikan materi agama tentang puasa dikelas masing-masing.

2) Berpartisipasi dalam kegiatan amal Jum'at, setelah pembacaan surat-surat pendek selesai, ketua kelas mengambil kotak amal yang ada di ruang guru, kemudian ketua kelas berkeliling mengidarkan kotak amal tersebut kepada teman-temannya satu persatu. Setelah itu, ketua kelas menghitung jumlah amal Jum'at yang didapat dan kemudian memberikan amal Jum'at itu kepada wali kelas untuk diberikan kepada pihak sekolah yang mengurusi amal Jum'at yang akan digunakan untuk kegiatan keagamaan di sekolah.

3) Mendo'akan teman, keluarga teman dan guru yang tertimpa musibah.

Jika ada teman, keluarga teman dan guru yang tertimpa musibah, siswa di pimpin oleh guru berdoa bersamasama untuk teman, keluarga teman dan guru yang sedang tertimpa musibah hal ini bertujuan agar siswa mempunyai rasa kepedulian terhadap sesama.

\section{b. Disiplin}

Dari hasil observasi diketahui bahwa penerapan pendidikan karakter melalui pembiasaan disiplin dilakukan melalui beberapa cara diantaranya :

1. Berbaris dengan tertib sebelum masuk kelas.

Kegiatan berbaris sebelum masuk kelas ini dilakukan setelah bel pagi berbunyi. Kegiatan ini dipimpin oleh ketua kelasnya masing-masing. Ketua kelas menyiapkan teman-temannya di depan kelasnya dengan memberikan aba-aba misalnya "siap gerak!", "luruskan!", "lurus!", kerapian!", dan "kerapian selesai!". Pada saat kerapian seluruh siswa merapikan seragamnya sendirisendiri mulai dari topi, dasi, baju, celana, kaos kaki dan tali sepatu. Setelah selesai dan seluruh siswa telah rapi, maka ketua kelas meminta temannya untuk masuk kelas sambil bersalaman kepada wali kelasnya yang telah berdiri di depan pintu yang dimulai dari barisan yang telah ditunjuk.

2. Mengikuti upacara bendera setiap hari Senin.

Kegiatan ini dilakukan setiap hari 
secara rutin. Upacara bendera dilaksanakan ketika bel berbunyi untuk memulai upacara, seluruh siswa berbaris per kelas di halaman sekolah dengan dipimpin oleh ketua kelasnya masing-masing. Sementara itu, petugas upacara digilir per kelas mulai dari kelas IV sampai kelas VI, sementara guru bertindak sebagai pembina upacara yang juga digilir

3. Mengikuti Senam Kesehatan Jasmani (SKJ).

Senam Kesehatan Jasmani (SKJ) di SD Negeri 6 Dawuhan Kabupaten Situbondo dilaksanakan sekali dalam seminggu yaitu hari Jum'at sebelum pelajaran dimulai. Kegiatan SKJ diikuti oleh siswa kelas I sampai kelas VI. Setelah bel berbunyi, seluruh siswa menuju halaman sekolah. Ketua kelas mengatur teman-temannya untuk persiapan SKJ. Setelah semua siap, ketua kelas mengambil tempat di depan teman-temannya dan di belakang instruktur senam yang kebetulan adalah guru olahraga di SD Negeri 6 Dawuhan Kabupaten Situbondo. Kegiatan ini berlangsung sekitar 30 menit. Dari keseluruhan aspek disiplin mulai berbaris dengan tertib sebelum masuk kelas, piket sesuai jadwal, mengikuti upacara bendera setiap hari Senin, dan mengikuti senam kesehatan jasmani (SKJ) semua sudah muncul dan telah menjadi kebiasaan di SD Negeri 6 Dawuhan Kabupaten Situbondo.

\section{c. Peduli Lingkungan}

Dari hasil observasi diketahui bahwa penerapan pendidikan karakter melalui pembiasaan peduli lingkungan dilakukan melalui beberapa cara diantaranya :

\section{Piket Sesuai Jadwal}

Kegiatan ini dilaksanakan siswa setelah jam pulang sekolah. Kegiatan ini dibagi menjadi beberapa kelompok dalam satu minggu. Kegiatan pada saat piket kelas ini antara lain menghapus papan tulis, merapikan kursi dan meja serta menyapu kelas. Sehingga keesokan harinya kelas suadah dalam kondisi bersih dan siap untuk digunakan lagi sebagai tempat yang nyaman untuk peroses pembelajaran

2. Membuang sampah pada tempatnya Membuang sampah merupakan kegiatan yang menuntut kesadaran dari masingmasing individu. Dari hasil pengamatan peneliti perilaku ini sudah mulai tampak meskipun masih perlu adanya himbawan dan tauladan dari guru. Untuk memberikan tauladan terhadap siswa, guru selalu membuang sampah pada tempatnya dan begitu juga ketika melihat siswa tidak membuang sampah 
pada tempatnya guru menegur siswa tersebut dan memintanya untuk membuang sampah pada tempatnya.

3. Memungut jika melihat sampah berserakan dan membuang pada tempatnya.

Kegiatan pembiasaan ini juga merupakan pembiasaan yang menuntut kesadaran tinggi dari masing-masing individu. Dari hasil pengamatan peneliti pembiasaan ini juga mulai kelihatan meskipun masih ada juga siswa yang kesadarannya masih perlu ditumbuhkan lagi. Menurut peneliti pembiasaan inilah yang perlu diberikan perhatian yang lebih karena memang tidak gampang menumbuhkan kesadaran untuk memungut sampah yang berserakan dan membuang pada tempatnya.

4. Melaksanakan kerja bakti sesuai perintah yang diberikan.

Kegiatan kerja bakti biasanya dilakukan ketika kondisi sekolah dan lingkungan sekitar sekolah sudah mulai tampak kotor. Dan kegiatan siswa pada saat kerja bakti diantaranya adalah membersihkan kelasnya masingmasing dan dilanjutkan dengan membersihkan lingkungan dalam sekolah seperti di halaman sekolah dan luar sekolah. Kegiatan ini biasanya dilakukan satu kali setiap bulannya dan biasanya dilaksanakan pada hari Jum'at.
Sehingga identik dengan Jum'at bersih. Secara keseluruhan aspek peduli lingkungan mulai piket sesuai jadwal, membuang sampah pada tempatnya, memungut sampah yang berserakan dan membuangnya pada tempatnya, serta melaksanakan kerja bakti semuanya sudah muncul meskipun perlu pengawasan dan tauladan yang baik dari kepala sekolah maupun guru di SD Negeri 6 Dawuhan Kabupaten Situbondo.

2. Implementasi Pendidikan Karakter Melalui Pembiasaan Nilai-nilai Karakter di SD Negeri 6 Dawuhan Kabupaten Situbondo

1) Nilai Religius

Penerapan nilai religius melalui pembiasaan terprogram di SD Negeri 6 Dawuhan Kabupaten Situbondo sebagai berikut:

a. Pondok Ramadhan

b. Berdoa bersama sebelum dimulainya pelajaran dan sesudah pembelajaran

c. Amal Jum'at

d. Mendo'akan teman, keluarga teman dan guru yang mengalami cobaan atau musibah.

\section{2) Nilai Disiplin}

Penerapan nilai disiplin melalui pembiasaan terprogram di SD Negeri 6 Dawuhan Kabupaten Situbondo. 

a. Upacara Bendera Hari Senin
b. Senam Kesehatan Jasmani (SKJ)
c. Berbaris sebelum masuk kelas
d. Bersalaman kepada guru sebelum masuk kelas

\section{3) Nilai Peduli Lingkungan}

Penerapan nilai peduli lingkungan melalui pembiasaan rutin di SD Negeri 6 Dawuhan Kabupaten Situbondo.

a. Piket sesuai jadwal sebelum pulang.

b. Membuang sampah pada tempat sampah.

c. Memungut sampah yang berserakan dan membuang pada tempatnya.

\section{KESIMPULAN}

Berdasarkan hasil penelitian yang dilaksanakan di SD Negeri 6 Dawuhan Kabupaten Situbondo, maka dapat ditarik kesimpulan sebagai berikut :

Dari pembahasan tentang Implementasi pendidikan karakter melalui pembiasaan di SD Negeri 6 Dawuhan Kabupaten Situbondo di atas, peneliti dapat menyimpulkan sebagai berikut.

1. Pelaksanaan pembelajaran pendidikan karakter di SD Negeri 6 Dawuhan Kabupaten Situbondo yang diutamakan melalui pembiasaan ada tiga yaitu, nilai relegius, nilai disiplin, dan nilai peduli lingkungan. Sedangkan pembelajaran nilai-nilai karakter melalui pembiasaan di SD Negeri 6 Dawuhan Kabupaten Situbondo dilaksanakan melalui kegiatan terprogram, kegitan rutin, dan kegiatan spontan. Konsep pendidikan karakter melalui pembiasaan di SD Negeri 6 Dawuhan Kabupaten Situbondo sesuai dengan hasil Sarasehan Nasional Pendidikan Budaya dan Karakter Bangsa. Nilai pendidikan karakter yang diutamakan melalui pembiasaan di SD Negeri 6 Dawuhan Kabupaten Situbondo yaitu (1) nilai relegius, (2) nilai disiplin dan (3) nilai peduli lingkungan. Penerapan nilai pendidikan karakter melaui pembiasaan SD Negeri 6 Dawuhan Kabupaten Situbondo dilakukan melalui tiga cara yaitu (a) pembiasaan terprogram, (b) pembiasaan rutin, dan (c) pembiasaan spontan.

2. Penerapan nilai religius melalui pembiasaan terprogram dilaksanakan melalui kegiatan keagamaan (Pondok Ramadhan). Penerapan nilai religius melalui pembiasaan rutin dilaksanakan melalui kegiatan pembiasaan berdoa bersama sebelum dimulainya pelajaran, berdoa bersama sebelum pulang sekolah dan Amal Jum'at. Penerapan nilai religius melalui pembiasaan spontan dilakukan melalui kegiatan mendoakan teman, keluarga teman dan guru yang 
mengalami cobaan atau musibah. Penerapan nilai disiplin melalui pembiasaan terprogram antara lain melalui upacara bendera setiap hari senin dan senam SKJ. Penerapan nilai disiplin melalui pembiasaan rutin antara lain melalui berbaris sebelum masuk kelas dan bersalaman kepada guru sebelum masuk kelas. Penerapan nilai peduli lingkungan melalui pembiasaan rutin antara lain melalui piket sesuai jadwal sebelum pulang dan membuang sampah pada tempat sampah. Penerapan nilai peduli lingkungan melalui pembiasaan spontan antara lain melalui dan membuang sampah pada tempatnya.

\section{DAFTAR PUSTAKA}

Agustino, Leo. (2012). Implementasi Kebijakan. Bandung : Alfabeta

Arifin, S., et al. (2010). Model Pendidikan Karakter CAK di ITS Menuju Kemuliaan Hidup Bermartabat : Strategi Implementasi. Surabaya: Arek ITS CAK

Barnawi dan M. Ariffin. (2012). Strategi dan Kebijakan Pendidikan Karakter. Yogyakarta: Ar-Ruzz Media.

Hasan, S. H. (2010). Pengembangan Pendidikan Budaya dan Karakter Bangsa. Jakarta: Pusat Kurikulum, Badan Penelitian dan Pengembangan, Kementerian Pendidikan Nasional.

Kemendiknas. (2010). Desain Induk Pendidikan Karakter. Jakarta: Kemendiknas.

Kusuma, Doni. (2012). Pendidikan Karakter: Strategi Mendidik Anak di Zaman Global. Jakarta : PT Grasindo

Nurdin, Diding dan Sibaweh, Imam. (2015). Pengelolaan Pendidikan. Jakarta : Rajawali Pers

Nurani,Soyomukti. (2015). Teori-teori Pendidikan Dari TRADISIONAL, (NEO) Liberal, MARXISSOSIALIS, Hingga POSTMODERN. Yogyakarta : ArRuzz Media

Nurul Zuriah. (2011). Metodologi Penelitian Sosial dan Pendidikan. Jakarta: Bumi Aksara

Noddings, N. (2010). Educating Moral People: A Caring Alternative to Character Education. New York: Teachers College Press

Suharjo. (2012). Mengenal Pendidikan Sekolah Dasar. Jakarta: Depdiknas.

Suwartono. (2014). Dasar-dasar Metodologi Penelitian. Yogyakarta : CV ANDI OFFSET 